\title{
Epistatic Basis of Mosaic Resistance in Mungbean [Vigna radiata (L.) Wilczek]
}

\author{
Kaushal Modha*, Prakash Patel, Shreya Sen, Aalok Shiv, Rupal Dhoot and Unnati Patel
}

Department of Genetics and Plant Breeding, N. M. College of Agriculture, Navsari Agricultural University, Navsari (Gujarat), India

*Corresponding author

\section{A B S T R A C T}

Hybridization was carried out between highly resistant genotype Meha and four susceptible genotypes viz., Pusa Vishal, GJM-1006, GM-4 and GJM-1008 to deduce genetics of Mungbean Yellow Mosaic Virus (MYMV) resistance in mungbean. Parents, $\mathrm{F}_{1} \mathrm{~s}, \mathrm{~F}_{2} \mathrm{~s}$ and $\mathrm{F}_{3}$ progenies were evaluated for their response to MYMV infection utilizing

\section{Keywords}

Duplicate Epistasis, MYMV, $\mathrm{F}_{3}$ progenies

\section{Article Info}

Accepted:

26 March 2018

Available Online:

10 April 2018 highly susceptible variety GM-4 as an infector row keeping one row of GM-4 after every two rows of parents, $\mathrm{F}_{1} \mathrm{~s}, \mathrm{~F}_{2} \mathrm{~s}$ and $\mathrm{F}_{3}$ progenies. No insecticides were sprayed to build up white fly vector population. Segregation pattern of resistance and susceptibility in $F_{2}$ generation indicated duplicate epistasis $(15: 1)$ which was confirmed by non-significant $\chi^{2}$ test. The proposed genotypes for Meha, susceptible male parents and hybrids are $R_{l} R_{l} R_{2} R_{2}$, $r_{1} r_{1} r_{2} r_{2}$ and $R_{1} r_{1} R_{2} r_{2}$, respectively. Ten resistant $\mathrm{F}_{2}$ plants were selfed to further confirm digenic duplicate epistatic nature of mosaic resistance. Out of ten $F_{3}$ progenies, seven progenies exhibited 15: 1, while three manifested 3: 1 segregation pattern of resistant and susceptible plants in support to duplicate epistasis. The proposed genotype of $\mathrm{F}_{2}$ individuals showing 15: 1 segregation pattern in $\mathrm{F}_{3}$ progenies is $R_{1} r_{1} R_{2} r_{2}$. While, $\mathrm{F}_{3}$ progenies indicating 3: 1 ratio predicted $F_{2}$ individual's genotype either as $R_{1} r_{1} r_{2} r_{2}$ or $r_{1} r_{1} R_{2} r_{2}$ from which they are derived. The results are also in accordance with the lineage of mosaic resistance in Meha from blackgram. The role of duplicate epistasis observed in present study will pave the ways to transfer mosaic resistance in high yielding susceptible cultivars as well as for molecular breeding of mungbean against MYMV infection.

\section{Introduction}

Mungbean [Vigna radiata (L.) Wilczek], belongs to Fabacease family, is well known self-fertilising diploid pulse crop of Asian countries with $2 \mathrm{n}=2 \mathrm{x}=22$ chromosomes and a genome size of $579 \mathrm{Mb}$ (Parida et al., 1990). It is one of the thirteen food legumes grown in India and third most important pulse crop of India after chickpea and pigeonpea. It is known by various names in India as mung, moong, but the name greengram is more common (Chatterjee and Randhawa, 1952).

Mungbean is an excellent source of high quality protein in the form of split pulse and fresh sprouts. Mungbean seeds are rich in protein, easily digestible and lack flatulence which makes it important component of balance diet. Seeds are also very good source 
of minerals (calcium, iron, zinc, potassium and phosphorus), vitamins (folate and vitamin K) and dietary fibres (Keatinge et al., 2011). Ascorbic acid is synthesized in sprouted seeds of mungbean with increment in riboflavin and thiamine. The protein is rich in lysine, an amino acid that is deficient in cereals.

Mungbean is grown in all seasons in India, however, summer cultivation during February to June is the most suitable growing period when there is a plenty of sunshine, high temperature and low humidity that keep insects and disease infestations at their lowest. Being a leguminous crop, it has the capacity to fix atmospheric nitrogen through symbiotic nitrogen fixation and is also used as a green manure crop. It is a short duration crop and therefore widely used as mixed intercrop or in crop rotation to improve nitrogen status of soil to break disease/ pest cycles.

Among various biotic stresses, mosaic disease caused by Mungbean Yellow Mosaic Virus (MYMV) drastically reduces yield up to cent per cent. Yellow Mosaic Disease (YMD) is caused by different species of whitefly transmitted geminivirus which belongs to genus begomovirus and family geminiviridae. Reports on losses due to disease revealed reduction of 9.6 to $38.2 \%$ in height, 7 to 28.5 $\%$ in fresh weight of shoot and 4.3 to $22.1 \%$ in dry weight, $25.7 \%$ in 1000 seed weight of susceptible cultivar (Premchand and Varma, 1983) and yield loss of $83.9 \%$ and a maximum growth reduction of $62.94 \%$ in MYMV infected cultivar (Quaiser Ahmed, 1991). MYMV disease on greengram was first ever reported from fields of IARI, New Delhi in 1960 and is transmitted principally by whitefly, Bemisia tabaci (Genn.) and grafting but not by sap, seed or soil (Nariani, 1960). MYMV causes irregular green and yellow patches in older leaves and complete yellowing of younger leaves. Yellow mosaic disease in northern and central India is caused by MYMIV, whereas the disease in southern and western India is caused by MYMV (Usharani et al., 2004). Affected plants produce fewer flowers and pods, pods often develop mottling, remain small and contain fewer and smaller seeds thus affecting yields qualitatively and quantitatively. Reduction in number of pods per plant, seeds per pod and seed weight are the main contributing factors for yield reduction upon mosaic infection (Nene, 1973; Dhingra and Chenulu, 1985). MYMV disease can be controlled by chemical, cultural and genetic methods. Nevertheless, host plant resistance is preferred over other methods because it is economical and eco-friendly approach. However, screening at hot spot with infector row is more reliable. Most efficient method of screening for MYMV resistance is force inoculation.

Knowledge on inheritance patterns is prerequisite for resistance breeding against mosaic disease in mungbean. Reports on genetics of mosaic resistance in mungbean varies from monogenic recessive to quantitative in nature (Khan et al., 2007; Dhole and Reddy, 2013; Jain et al., 2013; Kitsanachandee et al., 2013; Mahbubul Alam et al., 2014). In the present study, an effort was made to study genetics of mosaic resistance in mungbean utilizing five diverse parents.

\section{Materials and Methods}

To deduce the inheritance pattern of mosaic resistance, resistant genotype Meha was utilized as common parent and was crossed as female parent with susceptible male parents Pusa Vishal, GJM-1006, GM-4 and GJM1008. Pusa Vishal is tolerant genotype, however, symptoms do appear similar to susceptible genotypes at Navsari. Five parents, their resulting $\mathrm{F}_{1} \mathrm{~s}, \mathrm{~F}_{2} \mathrm{~S}$ and $\mathrm{F}_{3}$ progenies were evaluated for their reaction to mosaic in summer seasons during 2014 and subsequent 
years keeping highly susceptible variety GM-4 as an infector row (Fig. 1). Inter and intra row spacing was kept as $60 \mathrm{~cm}$ and $15 \mathrm{~cm}$, respectively. To build up whitefly vector population, the material was kept free from pesticides during all these evaluation trials. The reaction to disease was evaluated every
10 days after sowing and genotypes were characterized as resistant and susceptible according to Singh et al., (1988). Few resistant and susceptible $F_{2}$ and $F_{3}$ individuals were selfed to develop subsequent progenies to trace the inheritance pattern in subsequent segregating generations.

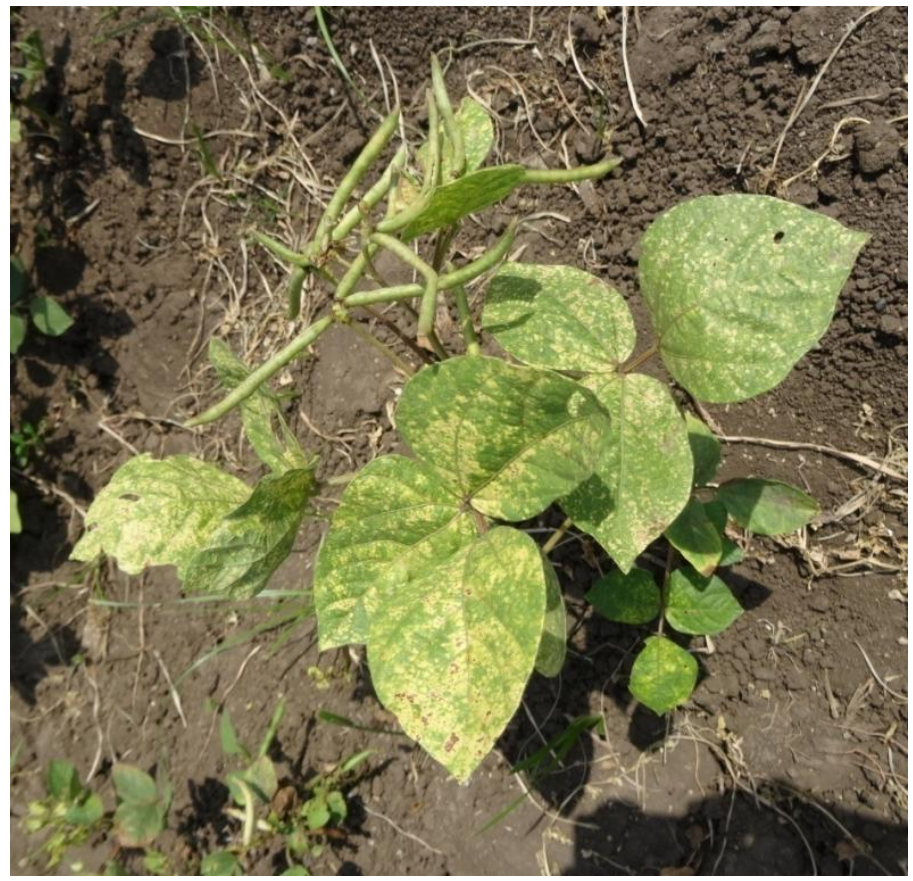

(a)
Infected GM-4 plant

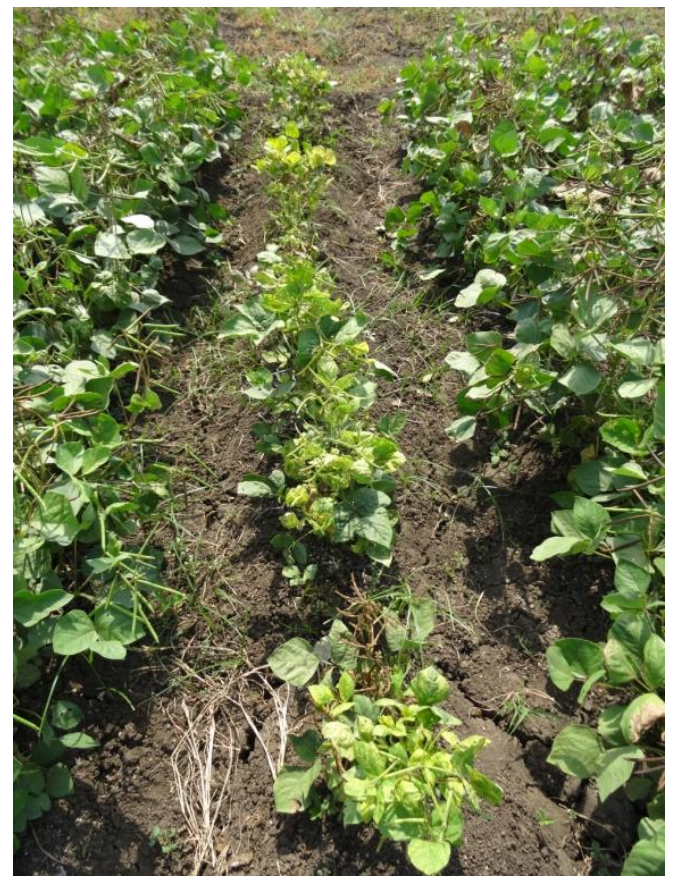

(b) Status of GM-4 infector row

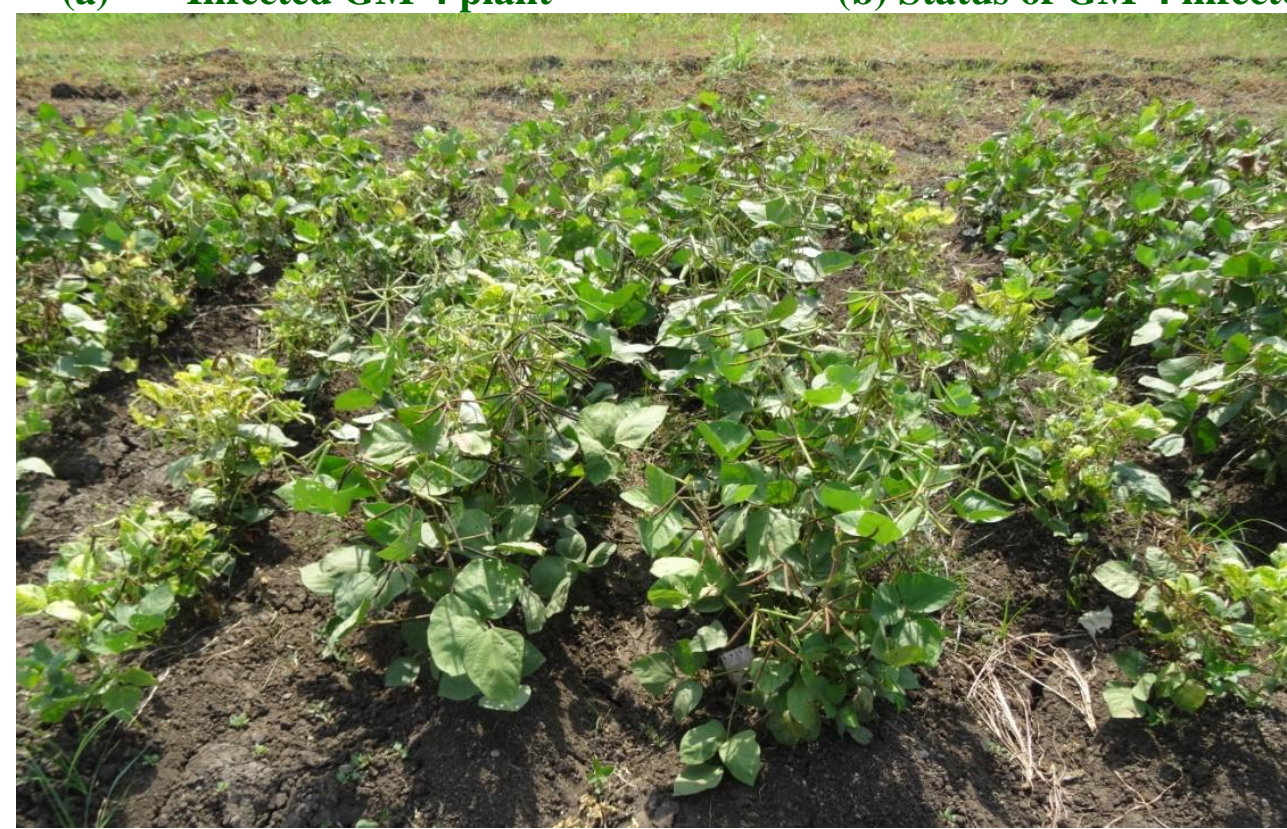

(c) Resistant $F_{3}$ progenies and heavily infected GM-4 infector rows

Fig.1 Status of infector row and $\mathrm{F}_{3}$ progenies 
Table.1 Observed and expected number of resistant and susceptible plants in different generations of four crosses in mungbean

\begin{tabular}{|c|c|c|c|c|c|c|c|c|c|}
\hline \multirow[t]{2}{*}{ Parents/ Cross } & \multirow[t]{2}{*}{$\begin{array}{l}\text { Proposed } \\
\text { genotypes }\end{array}$} & \multirow[t]{2}{*}{$\begin{array}{l}\text { Phenotypic } \\
\text { classes }\end{array}$} & \multicolumn{2}{|c|}{$\begin{array}{l}\text { Observed } \\
\text { number }\end{array}$} & \multicolumn{2}{|c|}{ Expected number } & \multirow[t]{2}{*}{$\begin{array}{l}\text { Expected } \\
\text { ratio }\end{array}$} & \multirow[t]{2}{*}{$\begin{array}{c}\chi^{2} \\
\text { value }\end{array}$} & \multirow{2}{*}{$\begin{array}{c}\text { Table } \chi^{2} \\
(1 \mathrm{df} \\
0.05)\end{array}$} \\
\hline & & & $\mathbf{R}$ & $\mathbf{S}$ & $\mathbf{R}$ & $\mathbf{S}$ & & & \\
\hline \multicolumn{10}{|l|}{ Parents } \\
\hline Meha & $R_{1} R_{1} R_{2} R_{2}$ & $\mathrm{R}$ & 20 & 00 & 20 & 00 & $1: 0$ & NA & NA \\
\hline Pusa Vishal* & $r_{1} r_{1} r_{2} r_{2}$ & $\mathrm{~S}$ & 00 & 20 & 00 & 20 & $0: 1$ & NA & NA \\
\hline GJM-1006 & $r_{1} r_{1} r_{2} r_{2}$ & $\mathrm{~S}$ & 00 & 20 & 00 & 20 & $0: 1$ & NA & NA \\
\hline GM-4 & $r_{1} r_{1} r_{2} r_{2}$ & $\mathrm{~S}$ & 00 & 20 & 00 & 20 & $0: 1$ & NA & NA \\
\hline GJM-1008 & $r_{1} r_{1} r_{2} r_{2}$ & $\mathrm{~S}$ & 00 & 20 & 00 & 20 & $0: 1$ & NA & NA \\
\hline \multicolumn{10}{|l|}{ Hybrids } \\
\hline (A) Meha x Pusa Vishal & $R_{1} r_{1} R_{2} r_{2}$ & $\mathrm{R}$ & 20 & 00 & 20 & 00 & $1: 0$ & NA & NA \\
\hline (B) Meha x GJM-1006 & $R_{1} r_{1} R_{2} r_{2}$ & $\mathrm{R}$ & 20 & 00 & 20 & 00 & $1: 0$ & NA & NA \\
\hline (C) Meha x GM-4 & $R_{1} r_{1} R_{2} r_{2}$ & $\mathrm{R}$ & 20 & 00 & 20 & 00 & $1: 0$ & NA & NA \\
\hline (D) Meha x GJM-1008 & $R_{1} r_{1} R_{2} r_{2}$ & $\mathrm{R}$ & 20 & 00 & 20 & 00 & $1: 0$ & NA & NA \\
\hline \multicolumn{10}{|l|}{$\mathrm{F}_{2} \mathrm{~S}$} \\
\hline (A) Meha x Pusa Vishal & \multirow{4}{*}{$\begin{array}{c}R_{1} R_{1} R_{2} R_{2} \\
R_{1} r_{1} R_{2} r_{2} \\
R_{1} r_{1} r_{2} r_{2} \\
r_{1} r_{1} R_{2} r_{2} \\
r_{1} r_{1} r_{2} r_{2}\end{array}$} & $\mathrm{R} / \mathrm{S}$ & 93 & 7 & 93.75 & 6.25 & $15: 1$ & 0.096 & 3.84 \\
\hline (B) Meha x GJM-1006 & & $\mathrm{R} / \mathrm{S}$ & 95 & 5 & 93.75 & 6.25 & $15: 1$ & 0.266 & 3.84 \\
\hline (C) Meha x GM-4 & & $\mathrm{R} / \mathrm{S}$ & 93 & 8 & 93.75 & 6.25 & $15: 1$ & 0.096 & 3.84 \\
\hline (D) Meha x GJM-1008 & & $\mathrm{R} / \mathrm{S}$ & 96 & 4 & 93.75 & 6.25 & $15: 1$ & 0.864 & 3.84 \\
\hline \multicolumn{10}{|c|}{$F_{3}$ progenies (Genotypes of susceptible individuals is $r_{1} r_{1} r_{2} r_{2}$ ) } \\
\hline $11 \mathrm{~A}$ & $R_{1} r_{1} R_{2} r_{2}$ & $\mathrm{R} / \mathrm{S}$ & 56 & 4 & 56.25 & 3.75 & $15: 1$ & 0.017 & 3.84 \\
\hline $40 \mathrm{~A}$ & $R_{1} r_{1} R_{2} r_{2}$ & $\mathrm{R} / \mathrm{S}$ & 58 & 2 & 56.25 & 3.75 & $15: 1$ & 0.871 & 3.84 \\
\hline $15 \mathrm{C}$ & $R_{1} r_{1} R_{2} r_{2}$ & $\mathrm{R} / \mathrm{S}$ & 58 & 2 & 56.25 & 3.75 & $15: 1$ & 0.871 & 3.84 \\
\hline $44 \mathrm{C}$ & $R_{1} r_{1} R_{2} r_{2}$ & $\mathrm{R} / \mathrm{S}$ & 57 & 3 & 56.25 & 3.75 & $15: 1$ & 0.160 & 3.84 \\
\hline $17 \mathrm{~A}$ & $R_{1} r_{1} R_{2} r_{2}$ & $\mathrm{R} / \mathrm{S}$ & 53 & 7 & 56.25 & 3.75 & $15: 1$ & 3.004 & 3.84 \\
\hline $56 \mathrm{C}$ & $R_{1} r_{1} R_{2} r_{2}$ & $\mathrm{R} / \mathrm{S}$ & 53 & 7 & 56.25 & 3.75 & $15: 1$ & 3.004 & 3.84 \\
\hline $65 \mathrm{C}$ & $R_{1} r_{1} R_{2} r_{2}$ & $\mathrm{R} / \mathrm{S}$ & 53 & 7 & 56.25 & 3.75 & $15: 1$ & 3.004 & 3.84 \\
\hline $13 \mathrm{~A}$ & $R_{1} r_{1} r_{2} r_{2} / r_{1} r_{1} R_{2} r_{2}$ & $\mathrm{R} / \mathrm{S}$ & 40 & 20 & 45 & 15 & $3: 1$ & 2.222 & 3.84 \\
\hline $60 \mathrm{C}$ & $R_{1} r_{1} r_{2} r_{2} / r_{1} r_{1} R_{2} r_{2}$ & $\mathrm{R} / \mathrm{S}$ & 41 & 19 & 45 & 15 & $3: 1$ & 1.422 & 3.84 \\
\hline $48 A$ & $R_{1} r_{1} r_{2} r_{2} / r_{1} r_{1} R_{2} r_{2}$ & $\mathrm{R} / \mathrm{S}$ & 47 & 13 & 45 & 15 & $3: 1$ & 0.355 & 3.84 \\
\hline
\end{tabular}

* - Pusa Vishal is tolerant but symptoms are similar to susceptible genotypes, R - Resistant, S - Susceptible, NA- Not applicable 


\section{Results and Discussion}

With a view to study heredity pattern of mosaic resistance in mungbean caused by MYMV which is very important economic pest, crossing was done between mosaic resistant genotype Meha with susceptible genotypes Pusa Vishal, GJM-1006, GM-4 and GJM-1008. The parents, their hybrids, subsequent generation and progenies were screened for their response to MYMV infection keeping highly susceptible variety GM-4 as an infector row. Evaluation was carried out during summer seasons as severe MYMV infection is observed during this season at Navsari. The observed and expected numbers of individuals along with chi-square test are presented in Table 1. All the plants of Meha and $F_{1}$ hybrids showed resistant reactions while all the plants of Pusa Vishal, GJM-1006, GM-4 and GJM-1008 exhibited susceptible reactions. Observed and expected number of individuals in four $\mathrm{F}_{2}$ populations along with non-significant $\chi^{2}$ value indicated duplicate epistasis as the data were perfectly in agreement with $15: 1$ segregation ratio of resistant and susceptible individuals. Confirming digenic duplicate epistasis, proposed genotypes of Meha, Pusa Vishal, GJM-1006, GM-4 and GJM-1008 are $R_{1} R_{1} R_{2} R_{2}, r_{1} r_{1} r_{2} r_{2}, r_{1} r_{1} r_{2} r_{2}, r_{1} r_{1} r_{2} r_{2}$ and $r_{1} r_{1} r_{2} r_{2}$, respectively. Similarly proposed genotype of $\mathrm{F}_{1}$ individuals is $R_{1} r_{1} R_{2} r_{2}$. To further confirm the result and trace the inheritance pattern of mosaic resistance, ten resistant plants viz., 11A, 40A, 15C, 44C, 17A, 56C, 65C, 13A, 60C and 48A from $F_{2}$ generation were selfed to obtain $\mathrm{F}_{3}$ progenies. Ten $\mathrm{F}_{3}$ progeny families each comprising of 60 individual plants were evaluated for their reaction to MYMV infection keeping GM-4 as an infector row. The segregation patterns of these progenies are depicted in Table 1. Of these, seven $\mathrm{F}_{3}$ progeny families obtained from $\mathrm{F}_{2}$ individuals viz., 11A, 40A, 15C, 44C, $17 \mathrm{~A}, 56 \mathrm{C}$ and $65 \mathrm{C}$ segregated in accordance with 15: 1 ratio of duplicate epistasis. The proposed genotype of these $F_{2}$ plants is $\mathrm{R}_{1} \mathrm{r}_{1} \mathrm{R}_{2} \mathrm{r}_{2}$. While, three $\mathrm{F}_{3}$ progeny populations obtained from 13A, 60C and 48A segregated in agreement with 3: 1 ratio. Proposed genotype of relevant $\mathrm{F}_{2}$ individuals for this kind of inheritance pattern is either $R_{1} r_{1} r_{2} r_{2}$ or $r_{1} r_{1} R_{2} r_{2}$. Besides, all the susceptible plants produced susceptible progenies (data not shown). In most of the previously reported results, monogenic recessive nature of mosaic resistance was observed by Malik et al., (1986 \& 1988), Thakur et al., (1997), Pal et al., (1991), Reddy and Singh (1995) or two recessive genes (Dhole and Reddy, 2012) or complementary recessive genes (Shukla and Pandya, 1985). Surprisingly, in our study, digenic duplicate epistasis was observed where two dominant genes together or alone are responsible for mosaic resistance. Meha is a very popular variety of mungbean and has been developed from the interspecific cross of Vigna radiata (Pant moong-2) and Vigna mungo (AMP-46) (Nadarajan and Gupta, 2010). In blackgram, monogenic dominant nature of resistance was reported by Dahiya $e t$ al., (1977), Kaushal and Singh (1988), Gupta et al., (2005) and Gupta et al., (2013), while it was reported to be digenic recessive by Singh (1980), Dwivedi and Singh (1985) and Verma and Singh (1986). Duplicate epistatic nature of mosaic resistance observed in present study is in agreement with previously reported results of Murugan and Nadarajan (2012), Durga Prasad et al., (2015) and Thamodran et al., (2016) in black gram. However, the results obtained are dependent upon genetic background, environment under which mosaic screening is performed as well as prevailing pathotypes in that area. The present findings will contribute to future breeding strategies aimed to incorporate mosaic resistance in mungbean. This information will also be useful for identification of molecular markers linked to mosaic resistance and molecular dissection of mosaic disease resistance. 


\section{References}

Chatterjee, D. and Randhawa, G. S. (1952). Standardized names of cultivated plants in India. II. Cereals, pulses, vegetables, and spices. Indian J. Hort., 9:64-84.

Dahiya, B. S., Singh, K. and Brar, J. S. (1977). Incorporation of resistance to mungbean yellow mosaic virus in blackgram (Vigna mungo L). Trop Grain Legume Bull., 9:28-32.

Dhingra, K. L. and Chenulu, V.V. (1985). Effect of yellow mosaic on yield and nodulation of soybean. Indian Phytopathol., 38: 248-251.

Dhole, V. J. and Reddy, K. (2012). Genetic analysis of resistance to mungbean yellow mosaic virus in mungbean (Vigna radiata). Plant Breeding, 131: 414-417.

Dhole, V. J. and Reddy, K. S. (2013). Development of a SCAR marker linked with a MYMV resistance gene in mungbean (Vigna radiata L. Wilczek). Plant Breeding, 132: 127-132.

Durga Prasad, A.V.S., Murugan, E. and Vanniarajan, C. (2015). Inheritance of resistance of mungbean yellow mosaic virus in Urdbean (Vigna mungo (L.) Hepper). Current Biotica, 8(4):413-417

Dwivedi, S. and Singh, D. P. (1985). Inheritance of resistance to yellow mosaic virus in a wide cross of blackgram (Vigna mungo L). Zeitschrift fur Planzenzuchtung, 95:281-284.

Gupta, S., Gupta, D. S., Anjum, T. K., Pratap, A. and Kumar, J. (2013). Inheritance and molecular tagging of MYMIV resistance gene in blackgram (Vigna mungo L. Hepper), Euphytica, 193(1): 27-37.

Gupta, S., Kumar, S., Singh, R. A. and Chandra, S. (2005). Identification of a single dominant gene for resistance to mungbean yellow mosaic virus in blackgram. SABRAOJ Breed Genet, 37:85-89.

Jain Rashmi, RoopaLavanya G., Reddy, P. A. and Babu, G. S. (2013).Genetic inheritance of Yellow Mosaic Virus Resistance in mungbean [Vigna radiata
(L.) Wilczek]. Trends in Biosciences, 6 (3): 305-306.

Kaushal, R. P. and Singh, B. M. (1988). Inheritance of disease resistance in blackgram (Vigna mungo) to MYMV. Indian J. Agric. Sci., 58:123-124.

Keatinge, J., Easdown, W., Yang, R., Chadha, M. and Shanmugasundaram, S. (2011). Overcoming chronic malnutrition in a future warming world: the key importance of mungbean and vegetable soybean. Euphytica, 180: 129-141.

Khan, M. G., Ahmad, W., Khattak, G. S. S., Din, S. U. and Ahmad H. (2007). Mode of inheritance of resistance to mungbean yellow mosaic virus (MYMV) in mungbean (Vigna radiata (L.) Wilczek). Sarhad J. Agric., 23(4): 1071-1074.

Kitsanachandee, R., Somta, P., Chatchawankanphanich, O., Akhtar, K. P., Shah, T. M., Nair, R. M., Bains, T. S., Sirari, A., Kaur, L. and Srinives, P. (2013). Detection of quantitative trait loci for mungbean yellow mosaic India virus (MYMIV) resistance in mungbean (Vigna radiata (L.) Wilczek) in India and Pakistan. Breeding science, 63(4): 367373.

Mahbubul Alam, A. K. M., Somta, P. and Srinives, P. (2014). Identification and confirmation of quantitative trait loci controlling resistance to mungbean yellow mosaic disease in mungbean [Vigna radiata (L.) Wilczek], Mol Breeding, 34:1497-1506.

Malik, I. A., Ali, Y. and Saleem, M. (1988). Incorporation of tolerance to Mungbean Yellow Mosaic Virus from local germplasm into exotic large seeded mungbean. In: S. Shanmungasundaram (ed.). Proc. Second Int'l. Symp. on mungbean, AVRDC Bangkok, Thailand, PP. $297-307$.

Malik, I. A., Sarwar, G. and Ali. Y. (1986). Genetic studies in mungbean (Vigna radiata (L.) Wilczek). Inheritance of tolerance to mungbean Yellow Mosaic Virus and some morphological characters. Pak. J. Botany, 18(2): 189 - 198. 
Murugan, E. and Nadarajan, N. (2012). Genetic studies on differential expression of mungbean yellow mosaic virus resistance related to trichome density in urd bean (Vigna mungo (L.) Hepper). Indian Journal of Plant Genetic Resources, 25(2): 135-138.

Nadarajan, N. and Gupta, S. (2010). Role of classical breeding in improvement of pulse crops. Electronic J. Plant Breed, 1(4):1099-1106.

Nariani, T.K. (1960). Yellow Mosaic of mung (Phaseolus aureus L.). Ind. Phytopathol, 13: $24-29$

Nene, Y. L. (1973). Control of Bamasia tabaci Genn. a vector of several plant viruses. Indian J. Agric. Sci., 43: 433-436.

Pal, S. S., Dhaliwal, H. S. and Bains, S. S. (1991). Inheritance of resistance to yellow mosaic virus in some Vigna species. Plant Breed, 106:168-171.

Parida A., Raina S. and Narayan R. (1990). Quantitative DNA variation between and within chromosome complements of Vigna species (Fabaceae). Genetica, 82:125-133.

Premchand and Varma. J. P. (1983). Effect of yellow mosaic on growth components and yield of mungbean and urdbean. Haryana Agricultural University Journal of Research, 13: 198-102.

Quaiser Ahmed. (1991). Growth attributes and grain yield of mungbean plants affected by mungbean yellow mosaic virus in field. Ind. Phytopatho., 43(4): 559-560

Reddy, K. R. and Singh, D. P. (1995). Inheritance of resistance to mungbean yellow mosaic virus. Madras Agric J, 88: 199-201.

Shukla, G. P. and Pandya, B. P. (1985). Resistance to yellow mosaic in Greengram. SABRAO Journal, 17 (3): 165-171.

Singh, D. P. (1980). Inheritance of resistance to yellow mosaic virus in blackgram (Vigna mungo L.). Theor Appl Genet, 52: 233235

Singh, G., Kapoor, S. and Singh, K. (1988). Multiple disease resistance in mungbean with special emphasis on Mungbean yellow mosaic virus In: International Symposium on Mungbean, 2nd Nov 1620 (1987) Bangkok, Thailand, pp 290296.

Thakur, R. P., Patel P. N. and Verma, J. P. (1997). Genetical Rela- tionship between Reaction to Bacterial Leaf Spot, Yellow Mosaic and Cercospora Leaf Spot Diseases in Mungbean (Vigna radiata $\mathrm{L}$. Wilczek). Euphytica, 26 (3): 765-774.

Thamodhran, G., Geetha, S. and Ramalingam, A. (2016). Genetic study in URD bean (Vigna mungo (L.) Hepper) for inheritance of mungbean yellow mosaic virus resistance. IJAEB, 9(1): 33-37.

Usharani, K. S., Surendranath, B., Haq, Q. M. R. and Malathi, V. G. (2004). Yellow mosaic virus infecting soybean in southern and Western India. Curr. Sci., 86(6): $845-850$.

Verma, R. P. S. and Singh, D. P. (1986). The allelic relationship of genes giving resistance to mungbean yellow mosaic virus in blackgram. Theor Appl Genet, 72: 737-738.

\section{How to cite this article:}

Kaushal Modha, Prakash Patel, Shreya Sen, Aalok Shiv, Rupal Dhoot and Unnati Patel. 2018. Epistatic Basis of Mosaic Resistance in Mungbean [Vigna radiata (L.) Wilczek]. Int.J.Curr.Microbiol.App.Sci. 7(04): 3265-3271. doi: https://doi.org/10.20546/ijcmas.2018.704.370 